\title{
Constantin von Monakow (1853-1930) and his legacy to science
}

\author{
Levent Sarikcioglu ${ }^{1}$
}

Received: 22 February 2017 / Accepted: 8 March 2017 / Published online: 24 March 2017

(C) Springer-Verlag Berlin Heidelberg 2017

\begin{abstract}
Constantin von Monakow was a Russian-born Swiss neurologist. Monakow was an outstanding scientist of his time. He will be remembered by his important contributions to our knowledge on the organization, location, and direction of tracts of the nervous system.
\end{abstract}

Keywords Constantin von Monakow · Monakow's bundle · Tracts of the nervous system

Constantin von Monakow was a Russian-born Swiss neurologist. Monakow was an outstanding scientist of his time. He will be remembered by his important contributions to our knowledge on the organization, location, and direction of tracts of the nervous system.

\section{His life}

Constantin von Monakow was born in 1853 in Wologda, an old city located on the Northwest of Russia (Fig. 1 and cover image). He was the youngest child of four in a noble family. His childhood was around the years of the Crimean War (October 1853-February 1856). After his mother's death in 1863, the family moved to Dresden and 3 years later to Zurich, where Monakow lived for most of his life. In 1872, he started to study medicine (against his father's will) [4]. In 1876, he worked as

Levent Sarikcioglu

levent@akdeniz.edu.tr; sarikcioglul@gmail.com

1 Department of Anatomy, Akdeniz University Faculty of Medicine, 07070 Antalya, Turkey assistant of Eduard Hitzig (1838-1907), professor of psychiatry at the Burghölzli Clinic in Zurich. In these years, Monakow had financial problems since he has no official position. But he never stopped his studies in science and clinical practice. To overcome money problems, he spent 1 year as a doctor of a ship traveling between Europe and South America [12]. His colleagues from the Burghölzli Clinic had been looking for a job for him to overcome his financial problems. In 1877, while returning to Europe, he was invited to be assistant physician in St. Pirminsberg in Pfäfers, Canton St. Gallen, Switzerland [4].

\section{Serial sectioning: a milestone in his scientific career}

Sectioning the human brain was particularly hard since it is too difficult the hold this soft tissue and cut it by ordinary microtomes [3]. To overcome these problems, many scientists worked on the development and manufacturing of microtomes. These problems were first overcome by Bernhard von Gudden's (1824-1886) in Munich. Gudden designed a new microtome which bears his name [3, 7]. In 1875 , on a journey through Germany, Monakov visited Gudden laboratory in Munich. Monakov and Gudden's meeting took only two days but this short meeting period raised very fruitful consequences on Monakow's future researches [12]. Gudden described his experimental studies on secondary degeneration and showed his microtome for large objects like human brain. Then, Monakow had experience on the usage of this microtome in 1878 since his institution at the St. Pirmingsberg asylum possessed the Gudden microtome [3]. This visit was a milestone in his scientific career. Monakow equated serial sectioning with modern neuroanatomical research methods [3]. 


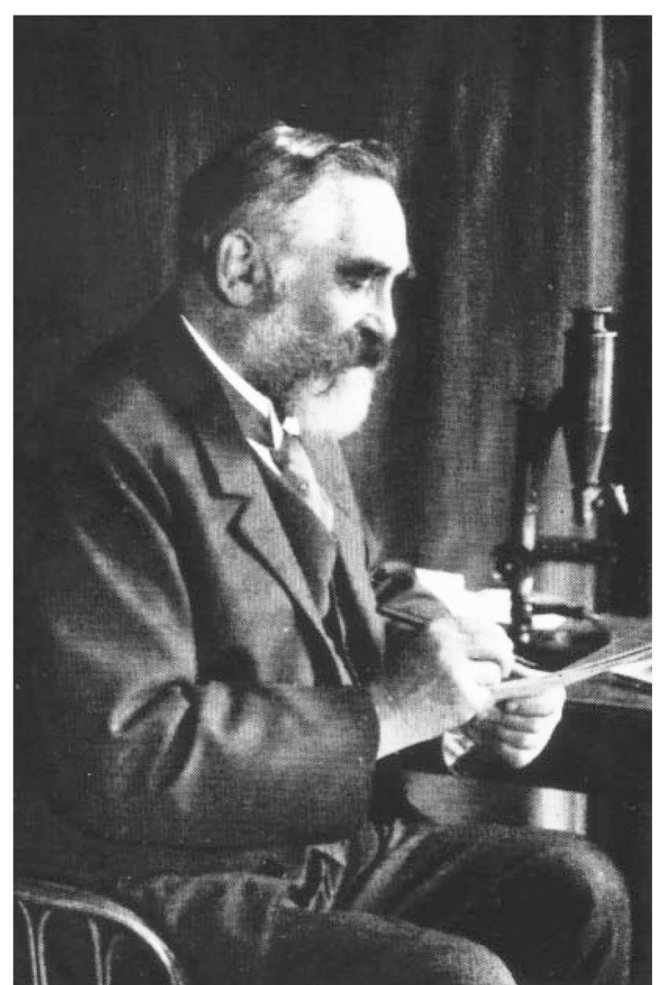

Fig. 1 and cover image: Photograph of von Monakov. Reproduced with the kind permission of Springer-Verlag Rights and Permissions

\section{His achievements and legacy}

On the basis of his knowledge gathered from the methods of serial sectioning and secondary degeneration, Monakow questioned the relations of the cerebral pathways and centers. In 1870, the damage of specific areas of the cortex caused atrophy in certain thalamic nuclei. Monakow performed his experiments on cats and rabbits that were reared with the help of a nurse of the St. Pirmingsberg asylum, Mathilde Rudio (she will be his wife in 1880) [4, 5].

Secondary degeneration occurs following surgical ablation of a discrete area of the nervous system. In 1870, Gudden provided the first experimental evidence of the secondary degeneration by showing ablation of the cortex in rabbits led in time to the death and disappearance of cell bodies in the thalamus. This method was later used to study neuroanatomic investigation of the connections in the nervous system [2]. In 1879, Monakow removed the occipital lobe of two newborn rabbits and survived them a full year. Then he observed evidences of the secondary degeneration in left corpus geniculatum externum, while the rest of the thalamus opticus (metathalamus) had remained intact [4]. This was a great discovery, and this observation resulted to planning further experiments to understand functional connections between thalamus and cortex [4].

Based on aforementioned experiments, von Monakow introduced the term "diaschisis" to indicate loss of function and signs of nervous system. This term derived from the Greek "diaschizein" (it means "separation" or "splitting") [1]. Von Monakow described diaschisis according to the connecting neuronal fibers involved: projection, association, and commissural fibers. He described diaschisis cortico-spinalis, diaschisis associative, diaschisis commisuralis [6].

His experimental studies on visual pathways were published in the German Archiv für Psychiatrie und Nervenkrankheiten as three consecutive parts [8-10]. He assembled these results for his habilitation thesis and medical faculty in Zurich accepted the thesis in 1885 . In 1887 , he started a private outclinic practice where he started building a collection of neuroanatomical preparations. His famous "Gehirnpathologie" contained over 3000 references was collected personally [6]. In 1894, Monakow became professor. He had contacts with Russian-origin scientists such as the neurologist-psychiatrist Vladimir Michailovitch Bechterev (1857-1927), the neurologist and neuroscientist Constantin von Economo (1876-1931), and biochemist and neurophysiolog Lina Stern (1878-1968). Monakow had also contacts with many internationally known scientists such as Cornelis Winkler (1865-1941), Jules Joseph Déjérine (18491917), Augusta Déjerine-Klumpke (1859-1937), and Gennosuke Fuse (1880-1946). In cooperation with Swiss neuropathologist Paul Charles Dubois (1848-1918), he founded the Swiss Neurological Association in 1909. The Swiss Archives of Neurology and Psychiatry (Schweizer Archiv für Neurologie und Psychiatrie) was also founded in 1917 by Monakow and his colleagues [5].

\section{His last years}

In 1923, Monakow retired as professor of neurology, but still continued to work in the neuroanatomical institute and his outpatient clinic [5]. He died peacefully from uremia in 1930. Reflections about his most interesting scientific life were published in 1970 entitled as "Vita mea - mein Leben" [11].

Acknowledgements The authors thank Akdeniz University Research Project Unit for their support.

\section{Compliance with ethical standards}

Conflict of interest The author declares no conflict of interest.

\section{References}

1. Engelhardt E, Gomes Mda M (2013) Shock, diaschisis and von Monakow. Arq Neuropsiquiatr 71:487-489. doi:10.1590/0004282X20130067

2. Giulian D (1997) Reactive microglia and ischemic injury. In: Caplan LR, Siesjo BK, Weir B, Welch KM, Reis DJ (eds) Primer on Cerebrovascular Diseases. Academic Press Ltd, p 121 
3. Hakosalo H (2006) The brain under the knife: serial sectioning and the development of late nineteenth-century neuroanatomy. Stud Hist Phil Biol Biomed Sci 37:172-202. doi:10.1016/j.shpsc.2006.03.010

4. Kesselring J (2000) Constantin von Monakow's formative years in Pfafers. J Neurol 247:200-205

5. Koehler PJ, Jagella C (2002) Constantin von Monakow (18531930). J Neurol 249:115-116

6. Pearce JM (1994) Von Monakow and diaschisis. J Neurol Neurosurg Psychiatry 57:197

7. Sarikcioglu L (2007) Johann Bernhard Aloys von Gudden: an outstanding scientist. J Neurol Neurosurg Psychiatry 78:195. doi:10.1136/jnnp.2006.106633

8. von Monakow C (1883) Experimentelle und pathologischanatomische Untersuchungen über die Beziehung der sogenannten
Sehspäre zu den infracortikalen Opticuszentren und und zum N. opticus (I). Arch Psychiatr Nervenkr 14:699-751

9. von Monakow C (1885a) Experimentelle und pathologischanatomische Untersuchungen über die Beziehung der sogenannten Sehspäre zu den infracortikalen Opticuszentren und und zum N. opticus (II). Arch Psychiatr Nervenkr 16:151-199

10. von Monakow C (1885b) Experimentelle und pathologischanatomische Untersuchungen über die Beziehung der sogenannten Sehspäre zu den infracortikalen Opticuszentren und und zum N. opticus (III). Arch Psychiatr Nervenkr 16:317-352

11. von Monakow C (1970) Vita mea - mein Leben. Huber Verlag, Bern,

12. Wiesendanger M (2006) Constantin von Monakow (1853-1930): a pioneer in interdisciplinary brain research and a humanist. Comptes rendus biologies 329:406-418. doi:10.1016/j.crvi.2006.03.011 